\title{
After the Great War: National Reconfigurations of Anthropology in Late Colonial Times
}

\author{
ANDRE GINGRICH
}

The ways in which we formulate our research questions always inform the results we obtain. "Anthropology in times of war" is a good example of a field in which to examine the formulation of research questions. A comparative perspective including present-day examples of, say, anthropologists "embedded" in US combat units during the Iraq war since 2003, or German anthropological counseling for NATO operations in northern Afghanistan in 2007, together with historical examples from World Wars I and II perhaps would yield results with a much stronger emphasis upon the more general fields of ethical dilemmas and of the constraints and risks that are involved in any anthropological engagement during times of war. By contrast, a discussion of "anthropology in times of war" through an exclusive focus on World War I is bound to emphasize the very specific historical circumstances and contingencies of that particular era and their impact upon academic developments. Such a focus is established throughout this book, and quite appropriately so in view of how little we still know about that crucial phase of the early twentieth century, about the anthropological disciplines' role in it, and how those years of armed conflict shaped the divergent courses of anthropological research.

The focus chosen for this volume therefore privileges the historical specificities of the World War I era. In many ways, World War I and its outcome put an end to a "long nineteenth century" and to some of its main imperial antagonists in Europe. The significance of colonial troops and of colonial interests, however, was substantial, and the role of the United States in the last year of the war outright decisive. Both factors-the colonial dimension and the USA's part in the war's outcome-make the term "World War" more than merely technical. From the outset, the global element in the term in fact indicates an earlier phase of globalizing tendencies that do connect that distant past with 
the present era. Those tendencies were shaped by late colonial and imperial rivalries which constituted the core of the Great War.

If our research questions to an extent always inform our results, then these questions are also inspired by the times and circumstances in which we live. Addressing in the early twenty-first century the interface between World War I and anthropology almost unavoidably introduces global and postcolonial perspectives. These perspectives are immediately and obviously relevant in the context of the colonial and transatlantic dimensions of this book's focus on World War I. In the context of anthropology's own history of that era, however, these perspectives are not so self-understood.

During the early years of the twentieth century, anthropology was increasingly elaborated in very diverse national directions, thereby leaving behind many of the global dimensions the anthropological fields had shared during their previous formative phases. In this sense, anthropology became part of the "end of scientific internationalism," as some ${ }^{1}$ have called what World War I accelerated, as well as brought about, across a whole range of academic fields. My present contribution ${ }^{2}$ argues that, as an outcome of World War I, an entirely new global academic landscape became established in the anthropological fields along national or quasi-national lines. These differing national directions soon gained momentum of their own and established themselves as new research traditions. The first part of this chapter presents a short overview of the major clusters of these new national anthropological traditions. Then, the second part addresses the German-speaking anthropological record in its World War I and post-World War I dimensions, as one core element in that new setting of nationalization in global anthropology. Institutional and disciplinary dimensions, methodological and theoretical orientations, as well as key actors and their political agendas will be assessed to identify some of the major contrasts and intersections among the national and quasi-national anthropological records.

1 Elisabeth Crawford, Nationalism and Internationalism in Science, 1880-1939: Four Studies of the Nobel Population (Cambridge, UK: Cambridge University Press, 1992); for the nineteenth century's last quarter, see also the excellent analysis by Chris Manias, "The Race prussienne Controversy: Scientific Internationalism and the Nation," Isis 100 (2009): 733-757.

2 For their very helpful comments and suggestions about an earlier version of this chapter, I am particularly grateful to Matti Bunzl (Urbana-Champaign), Henrika Kuklick (Philadelphia), Britta Lange (Berlin-Vienna), Peter Schweitzer (Fairbanks), and Maria Six-Hohenbalken (Vienna). I also thank Monique Scheer (Berlin) and Reinhard Johler (Tübingen) as coeditors of this volume and as hosts of the preceding conference for their substantial input. Finally, I wish to thankfully acknowledge the editorial assistance of Julene Knox (London). 


\section{Anthropology's Emerging National Traditions during World War I}

The rationale of the present argument claims that national and quasinational traditions constituted the core of anthropology's history throughout the "short twentieth century" (1914-1989), spanning what we today may call anthropology's first modernity. These hegemonic, competing national traditions emerged before, during, and after World War I and became fully established as a by-product of World War I. The global and postcolonial perspectives of anthropology today in its second modernity will thus also allow us to raise new questions about the eve of that first modernity, when the late colonial world had already become increasingly global in commercial, political, and military ways, while anthropology embarked upon its diverse national trajectories.

\section{Two Traditions Apart: the SOVIET Union (RUSSia) AND the USA}

The two countries that were to emerge from World War II as the superpowers of the Cold War both played very different, but equally discontinuous, roles during World War I. Imperial Russia was the major eastern ally of the western powers until the Czar's Empire collapsed in 1917. After Lenin's Bolshevik party came to power with some German assistance, the new leaders signed a separate peace accord in Brest-Litovsk with the Central Powers, which signaled a possible change of developments for the western front as well. The United States, on the other hand, had refrained from entering World War I until that point, but their eventual participation effected the decisive turning point for the war's outcome. Toward the end of the war, the leaders of both countries thus were able to present themselves as rival messengers of a new era, and as representing political forces with programs that were entirely distinct from those of other main antagonists in World War I. In particular, this messenger role related to national and colonial questions. On behalf of the United States, Woodrow Wilson presented the "fourteen points" program with its emphasis on sovereignty and self-determination. Again, in a different, but parallel, emphasis, Lenin's party declared that self-determination of oppressed nations and colonies was part of its political agenda. Beyond their widespread propaganda effects upon public opinion in Europe and elsewhere, these declarations also had a limited and partial practical impact upon the treaties of Brest-Litovsk, St. Germain, and Versailles.

The courses that anthropology took during the war years in both countries were quite different from each other and, in fact, also from what went on in 
western and Central Europe. For the Russian Empire, Marina Mogilner ${ }^{3}$ shows how deeply physical anthropology was institutionalized within the army, where it contributed to the Czar's war effort. This kind of physical anthropology largely followed a descriptive and pragmatic orientation, which only reluctantly accepted the inclusion of ethnic and national criteria and displayed little inclination toward any explicit racism. Taken together, the three main schools of physical anthropology before 1917 did play a more central role in imperial academic life than the various larger and smaller centers of ethnography, which mostly led a relatively separate existence only at museums. So far, little evidence has come to light of any substantial involvement of Russian ethnography in the World War I effort.

The institutional beginnings of Soviet ethnography had emerged out of the Petrograd Institute of Geography, and Soviet ethnography would always maintain a specific disciplinary affinity to geography. After the 1917 revolutions, the relationship between physical anthropology and ethnography in Russia became almost inversed. Physical anthropology under Soviet rule was downgraded to a position of minimal significance. By contrast, ethnography received growing attention and public support under the Marxist premise of what was now becoming the Soviet Union. The underlying reasons were political, in an ideological as much as in a pragmatic sense: In ideological terms, it was believed that ethnography-in the evolutionist tradition of Karl Marx's and Friedrich Engels's interpretations of L. H. Morgan's works-could provide additional substantiation for Marxist theory. In pragmatic political terms, ethnography was regarded as a key tool for ruling the non-Russian peoples of Siberia, central Asia, and the Caucasus regions. In spite of these dramatic shifts of political and institutional contexts, and notwithstanding the formal insertion of Marxist dogma, Peter Schweitzer ${ }^{4}$ has shown that some continuity with pre-1917 Russian ethnography was maintained well into the early 1930s, which was primarily based on the work of Lev Sternberg and Vladimir G. Bogoras. ${ }^{5}$ Both were evolutionists, but while Sternberg was close

3 See Marina Moligner in this volume; see also idem, "Russian Physical Anthropology in Search of 'Imperial Race': Liberalism and Modern Scientific Imagination in the Imperial Situation," Ab Imperio 8, no. 1 (2007): 191-223.

4 Peter Schweitzer, "Siberia and Anthropology: National Traditions and Transnational Moments in the History of Research" (habilitation thesis, University of Vienna, 2001).

5 Igor Krupnik, "The 'Bogoras Enigma': Bounds of Culture and Formats of Anthropologists," in Grasping the Changing World:Anthropological Concepts in the Postmodern Era, ed. Vaclav Hubinger (London: Routledge, 1996), 35-52; idem, "Jesup Genealogy: Intellectual Partnership and Russian-American Cooperation in Arctic/North Pacific Anthropology, Part I, From the Jesup Expedition to the Cold War, 1897-1948," Arctic Anthropology 35, no. 2 (1998): 199-226. 
to Marxism and had been quoted by Engels, Bogoras displayed some affinity to German geographic diffusionism, including the work of anthropogeographer Friedrich Ratzel. In a way, therefore, evolutionist Marxism combined with some less visible Ratzelian influences ${ }^{6}$ was forging the new Soviet ethnography, with its primary focus on non-Russians in the USSR, a strong historical and a weaker social science component, and a rigid territorial emphasis on typological distinctions.

This first strand of Soviet ethnographic tradition continued until the late 1930s, when it was destroyed by Stalin's terror. After 1945, a second strand of ethnographic tradition had emerged, which partially built on the first through key concepts, such as "historical-ethnographic provinces." The second tradition was exported, and was imposed upon many other countries of the communist world in east Central Europe and elsewhere.

In the United States, Franz Boas had established what became known as the four-field approach in anthropology already some time before 1914. Including physical, archaeological, linguistic, and cultural anthropology, this approach could steadily consolidate and expand while the United States refrained from entering the war. During these first war years, Boas's reputation suffered a public and institutional setback after he criticized anti-German spy activities among some of his American colleagues. It took him and his supporters several years to overcome this setback after the war. The influence of nineteenthcentury German liberal academic traditions upon Boas's four-field approach has often been outlined, and quite rightly so. ${ }^{7}$ It is also necessary to emphasize that, while Boas had left some of the less liberal German traditions behind him, he also modified and reshaped those elements that he did take with him, giving them new directions for their new US contexts. Within the four-field approach, for instance, the four subfields basically enjoyed an equal standing that had not been understood in the German context from which Boas had taken inspiration and where physical anthropology continued to dominate. It is also noteworthy that, in the United States, the four-field approach never explicitly included folklore studies. ${ }^{8}$ Boas had initiated the foundation of an

6 The most prominent Ratzelian in Soviet ethnography was Petr Fedorovich Preobrazhenskiy, who, in the course of Stalin's terror, was arrested in 1937 and shot in 1941 (Schweitzer, "Siberia and Anthropology").

7 Matti Bunzl, "Franz Boas and the Humboldtian Tradition: From Volksgeist and Nationalcharakter to an Anthropological Concept of Culture," in Volksgeist as Method and Ethic: Essays on Boasian Ethnography and the German Anthropological Tradition, ed. George W. Stocking Jr. (Madison, WI: University of Wisconsin Press, 1996), 17-78; Douglas Cole, Franz Boas: The Early Years, 1858-1906 (Vancouver: University of Washington Press, 1999).

8 In this chapter, I apply the term "folklore (studies)" in the sense in which it was used at the beginning of the twentieth century in the English-speaking 
academic folklore association and a corresponding journal, ${ }^{9}$ but he envisioned an institutional and academic development for these folklore studies apart from, and outside of, anthropology proper. This was an evident continuation of J. G. Herder's distinction between Naturvölker and Kulturvölker. With its focus on the respective domestic majority population, this kind of folklore approach paralleled similar developments in the Germany of Boas's times.

In theoretical and methodological terms, the four-field approach promoted close interdisciplinary cooperation between the natural sciences and humanities on an explicitly nonracist basis, which avoided the establishment of any quick correlation between physical and cultural diversities. With its focus on local histories and empirically corroborated diffusion processes, Boas's program accentuated the basic equality of human biological and cultural diversity. Academically and intellectually, this program was already fairly well established within the United States toward the end of the war. In physical anthropology, some schools competed with the Boasians, and several among them pursued explicitly racist orientations until well into the late 1920s. To some extent, Boas's program received a certain public boost from Wilson's Fourteen Points, when they became part of general discourse and public opinion. The political call for national self-determination and an academic program focusing on humans' biological and cultural equality corresponded with each other. US-American interwar isolationism, however, did not create too friendly an environment for the Boasian enterprise at first. Still, the intellectual influence of Boasian anthropology slowly but gradually continued to grow within and also beyond the United States after World War I. In an institutional sense, however, the four-field approach was not going to be successful anywhere outside of North America.

\section{Two Related Traditions: the UK and France}

Henrika Kuklick ${ }^{10}$ clearly demonstrates the very limited intellectual and research impact which World War I had on anthropology in the British realm. The main academic journals of those years testify to only a modest increase in concern on the part of physical anthropology for war-related themes, and to a refined distinction between topics that were dealing with human biology

academic world and as an equivalent of what emerged at the same time as Volkskunde in German.

9 Regina Bendix, In Search of Authenticity: The Formation of Folklore Studies (Madison, WI: University of Wisconsin Press, 1997).

10 See Henrika Kuklick in this volume; see also idem, "The British Tradition," in A New History of Anthropology, ed. idem (Oxford: Blackwell, 2008), 52-78. 
and race and those that related to society and culture. In anthropology, the war years coincided with the peak of A. C. Haddon's and W. H. R. Rivers's academic influence at home, while the young Polish immigrant Bronislaw Malinowski embarked upon his ethnographic enterprise in the Pacific. By and large, the war accelerated developments that were already under way. The outbreak of the war, and his own status as an alien citizen, certainly promoted the kind of fieldwork by Malinowski that would become paradigmatic-but even that had its conspicuous precursors, which ranged from the Torres Straits Expedition ${ }^{11}$ to Heinrich Barth, Alois Musil, ${ }^{12}$ and Franz Boas. ${ }^{13}$ Other research developments that were accelerated by the war included the ongoing separation between physical anthropology and social anthropology, with continuing relevance for evolutionism in the former and its demise in the latter. Although linguistic, physical, and social anthropology remained combined in some major departments (Oxford, Cambridge, University College London), the discrete establishment of social anthropology as a social science emerged to an extent that would make it prevail in the UK, at first, and in the British Empire during the decades that followed.

Some further research may still be necessary to clarify whether British anthropologists contributed to the recruitment and training of any colonial forces. The evidence that has been presented so far, however, indicates that British anthropologists' involvement remained quite limited in most of these more applied and practical fields during World War I. ${ }^{14}$ In an intellectual sense, the Great War therefore promoted British physical anthropology's coherent integration into the natural and life sciences. By contrast, social anthropology in the UK and the British realm went through its shorter diffusionist phase only to become, under Malinowski first and then A. R. Radcliffe-Brown, part of the social sciences.

On the other side of the Channel, developments in French anthropology were not as different from the UK as one perhaps might intuitively expect. Long before World War I, Émile Durkheim had already established his sociological school, which included ethnography and social anthropology as

11 Fredrik Barth, "Britain and the Commonwealth," in One Discipline, Four Ways: British, German, French, and American Anthropology; The Halle Lectures, by Fredrik Barth, Andre Gingrich, Robert Parkin, and Sydel Silverman (Chicago, IL: University of Chicago Press, 2005), 3-60.

12 Andre Gingrich, "Ruptures, Schools and Nontraditions: Re-Assessing the History of Sociocultural Anthropology in German," in One Discipline, Four Ways, 61-153.

13 Michael W. Young, Malinowski: Odyssey of an Anthropologist, 1884-1920 (New Haven, CT: Yale University Press, 2004).

14 Henrika Kuklick, The Savage Within: The Social History of British Anthropology (1885-1945) (Cambridge, UK: Cambridge University Press, 1991). 
distinct and different parts. ${ }^{15}$ The social anthropology of Durkheim's school thus clearly belonged to the emerging social sciences, and it displayed little institutional and intellectual affinity at all to physical anthropology. One could argue that, in this sense, French anthropology at the outbreak of World War I had advanced even further than its British counterpart. This is also confirmed by the formative influence of Durkheim's reasoning upon the intellectual profile of Radcliffe-Brown. ${ }^{16}$ The war itself and its devastations, however, did not so much accelerate, but rather postpone and impede, further developments of anthropology in France. This was related not least to the fact that some of the war's most important battlefields were located on French soil. In addition, the war took its toll among some of Durkheim's most brilliant students, such as Robert Hertz. ${ }^{17}$

Both Durkheim and his immediate disciples were essentially armchair anthropologists, who appreciated the results of fieldwork by others, but did not promote it themselves. Consequently, their kind of anthropology was regarded as fairly useless in any practical sense by the French Republic in its colonial and World War I efforts. Much of the early ethnographic fact-finding by the French was carried out by missionaries, colonial administrators, or individual scholars outside the Durkheim school. The available evidence suggests a correspondingly minimal role for French anthropologists in the recruitment and training of colonial troops, although this might also require additional research. In view of the war losses and of anthropology's institutional weakness, it took Durkheim's nephew and foremost disciple Marcel Mauss some time after the war to put social anthropology back on track again. ${ }^{18}$ The Durkheim school was not the only one in France during the two decades following World War $\mathrm{I},{ }^{19}$ but its growing importance contributed to the enduring separation between ethnography and social anthropology as a social science, and physical anthropology as belonging to the natural and life sciences.

France and Britain were the two major European powers which fought and won World War I. In turn, this enabled them to reorganize the late colonial world in the war's aftermath according to their own interests. The available evidence suggests that anthropologists' academic involvement in the French and British World War I efforts was minimal. In both cases, post-World War I

15 Gérald Gaillard, The RoutledgeDictionaryofAnthropologists(London:Routledge, 2004).

16 Adam Kuper, Anthropology and Anthropologists: The Modern British School, 3rd ed. (London: Routledge, 1996).

17 Robert Parkin, "The French-Speaking Countries," in One Discipline, Four Ways, 157-256.

18 Wendy James and Nick J. Allen, eds., Marcel Mauss: A Centenary Tribute (Oxford: Berghahn, 1998).

19 Gaillard, The Routledge Dictionary of Anthropologists. 
developments in anthropology featured a wide-ranging integration of physical anthropology in the natural sciences, the ongoing academic establishment of social anthropology as a distinct social science, and thus a far-reaching separation between the two. Equally significant was the fact that neither in the British nor in the French academic landscapes did any specialized research discipline emerge that would exclusively focus on folklore studies or on any similar field. Such studies were of course carried out in Britain as well as in France. ${ }^{20}$ Scholars in this field often had their own museums and sometimes also their own journals and associations. Yet, on the level of academic teaching, degrees, and university institutions, folklore studies in the French and British national and colonial realms would always remain an integral, nonspecialized subfield of social anthropology. This inclusion into social anthropology more broadly, and its simultaneous separation from physical (or biological) anthropology, demarcates a distinct, northwest European trajectory in anthropology's first modernity. If World War I had any effect on this tradition, then it was in a double sense: The war helped to further consolidate this orientation, and its implementation after 1918 promised to make sense of a newly arranged colonial world.

\section{A Cluster of New Beginnings: Anthropology in Europe's Newly Independent Countries}

An originally very small group of old, independent, and noncolonial European countries (among them Switzerland and the special case of Sweden's union with Norway) had gradually become enlarged during the nineteenth century as a result of the Ottoman Empire's continuing demise, leading to the establishment of the independent states of Greece, Romania, Serbia, and Bulgaria. In a sense, however, this had only been the first wave of what became a virtual flood of new declarations of independence before, during, and, most importantly, after World War I. This flood swept through northern, Central, and southeastern Europe and included Ireland (1922), Norway (1905), Finland (1917), the Baltic countries (1918), Poland (1918), Czechoslovakia (1918), Yugoslavia (1918), and Albania (1912). On an evidently less voluntary basis, this list of newly established, noncolonial countries with new borders also included, after the war, the core remainder states of two former empires, that is, Austria, Hungary, and Turkey.

Any attempt to understand anthropology's European trajectories following World War I would be quite futile without a basic acknowledgment of the fact that more than half of Europe's political landscape was redrawn and

20 Isaac Chiva and Utz Jeggle, eds., Deutsche Volkskunde_Französische Ethnologie: Zwei Standortbestimmungen (Frankfurt a. M.: Campus, 1987). 
rewritten immediately before, during, or after the Great War. None of these new countries had any colonies elsewhere. From today's perspective, some of those new states (e.g., Czechoslovakia or Yugoslavia) resembled federal rather than nation states. In their time, however, most of them certainly promised to fulfill national aspirations and longings in one way or another, and, in that sense, they did represent widespread local sentiments. Identifying, praising, and popularizing their respective national cultural traditions therefore became a pressing public agenda in the new institutional contexts of each of these countries. Where this had previously been at all possible, it was now important to redefine and reassess. Everywhere, it became necessary to collect, to document, to invent, to interpret, and to display. These were the great times of folklore studies, or of disciplines with different names but similar topics. As a cluster of specialized academic disciplines with distinct teaching programs, degrees, university departments, and, equally important, with corresponding museum collections and museums they quickly gained academic respectability and public support in most parts of northern, Central, and southeastern Europe. Studying and teaching "local cultures at home" was a political priority and thus an educational necessity which brought a number of earlier developments from the late eighteenth and nineteenth centuries to an unprecedented peak. These studies usually put a certain emphasis on historical origins, and they maintained a relatively stable focus on preindustrial rural material culture as well as on oral and musical traditions. Because of national political and ideological priorities, the methodological focus in these studies was usually not comparative, but particularist. Their historicist and particularist focus, plus their strong relationship to national language traditions, clearly placed these research records within the wider fields of the humanities. By and large, the influence of historicism and of geographical determinism was thus relatively strong in these fields. In some cases, this cross-fertilized with creative new sources of inspiration from other fields, as most notably in Polish and Czech linguistic studies. ${ }^{21}$

In most contexts in these newly independent states, ethnographic research on any cultures other than one's own was impossible for lack of funding or had little relevance because of national priorities. Some exotic ethnographic collections continued to exist as the decontextualized remains of a now bygone imperial past; the post-1918 Helsinki and Prague museum departments are two well-known cases in point. In a few other cases, the search for one's own ethnic origins had developed into very specific expertise about distant, but allegedly ethnically related cultures, as is testified by early Hungarian and Finnish exper-

21 Roy F. Ellen, Ernest Gellner, Grazyna Kubica, and Janusz Much, eds., Malinowski between Two Worlds: The Polish Roots of an Anthropological Tradition (Cambridge, UK: Cambridge University Press, 1988). 
tise in Finno-Ugric cultures. ${ }^{22}$ Both of these exotic exceptions-the by-products of an imperial past as much as the results of researching one's distant originswere easily subsumed under the typical priority given to ethnographic folklore studies. These studies represented a top political agenda in the cultural and educational fields of Europe's newly independent states after 1918. If considered at all, then certain elements of sociocultural anthropology were integrated into this priority. By necessity and by definition, the early institutionalized research activities of folklore studies in these newly independent countries could not possibly be free from nationalist ideologies, which defined and demanded their installation. Sometimes, the impact of these nationalist ideologies in academia represented one combination or another of revitalized older forms of Central European romanticism with more recent local political ideologies. The quality and the extent of these nationalist ideologies, however, differed widely. In addition, it should be emphasized that nationalist ideological elements in folklore studies per se excluded neither some degree of empirical accuracy nor liberal elements: On the contrary, some versions of nationalism may combine very well with liberal orientations within uncontested national boundaries. ${ }^{23}$

As for physical anthropology, Marius Turda ${ }^{24}$ and Christian Promitzer ${ }^{25}$ have provided exemplary historical case studies for Hungary, Bulgaria, and Serbia, while similar studies for physical anthropology in the newly independent countries of northern Europe still need to be carried out. It might still be somewhat early to draw wider conclusions from these three countries for others in Central and southeastern Europe - after all, with Bulgaria and Hungary, two of these three cases represent successor states to the Central Powers in World War I. At least for these cases, however, Turda's argument for Hungary about an inherent racism in physical anthropology under a nationalist premise deserves careful consideration. The existing evidence for Central and southeastern Europe's physical anthropology during those decades at any rate indicates very diverse profiles. Intellectually, it ranged from explicit racism as in the Serbian version of physical anthropology to less ideologically charged empiricism. Institutionally, physical anthropology remained loosely linked to ethnographic and folklore studies at home in some cases, which promoted

22 Schweitzer, "Siberia and Anthropology."

23 Ernest Gellner, Nations and Nationalism (New York: Cornell University Press, 1983).

24 Marius Turda, The Idea of National Superiority in Central Europe, 1880-1918 (New York: Edwin Mellen Press, 2005); idem, "Race, Politics and Nationalist Darwinism in Hungary, 1880-1918," Ab Imperio 8, no. 1 (2007): 139-164.

25 See Christian Promitzer in this volume; idem, "Vermessene Körper: 'Rassenkundliche' Grenzziehungen im südöstlichen Europa," in Europa und die Grenzen im Kopf, eds. Karl Kaser, Dagmar Gramshammer-Hohl, and Robert Pichler (Klagenfurt: Wieser, 2003), 384-387. 
their ideological juxtaposition. In other cases, such as the Bulgarian example discussed by Promitzer, ${ }^{26}$ physical anthropology developed along lines that were largely independent from those in ethnography and folklore studies. As a provisional summary, we may thus refer to a partial intertwinement between physical anthropology and folklore studies during the early years of Europe's newly independent states. The context of new national priorities indicates that, by and large, ethnography and folklore studies in most cases took priority over physical anthropology, during those early years at least. In anthropology's post-1918 European contexts, this internally heterogeneous context of a strong emphasis on folklore studies at home, a weak and partially interconnected physical anthropology, and very few elements of cross-cultural anthropology represented a specific configuration that differed markedly from those discussed so far. It never gained wider international recognition, but in one or the other version, until World War II, it often prevailed locally in this newly independent half of Europe.

\section{Reassessing the Impact of World War I on Anthropology's Fields in the German-Language Zone}

The preceding overview sketches some of the major ways in which different national and quasi-national traditions in anthropology developed during and after World War I, and it allows us to present some conclusions for the anthropological fields in the German-speaking context. In an intellectual and institutional sense, three main features can be emphasized. These are (a) the collapse of previous global interactions and accelerated national reinvention after the outbreak of the war, (b) the uniquely intense military engagement of German and Austrian anthropologists during the war, and (c) the elaboration of a new and distinct national setting for post-1918 anthropology in German.

\section{Outbreak of World War I: Collapse of Global Communication and Accelerated National Reorientation}

Since the late eighteenth and throughout the nineteenth century, the Germanspeaking countries had had far-reaching and very diverse influences on the international formative phases of these anthropological fields. These earlier influences of course had never been one-sided, that is, simply emanating from

26 Idem in this volume. 
German-speaking countries: They took many directions and were accompanied by the absorption into the German-language zone of even more influences from elsewhere. In most cases, this had involved a more active participation by the centers of imperial and colonial powers and a less active role on the part of academic networks in the younger and newly independent academic institutions.

Still, within these evolving, hierarchically structured imperial and colonial relations before 1914, a competitive global academic landscape had thrived, to which a German-speaking anthropology in the making had rendered many substantial, albeit quite heterogeneous, contributions. We have seen that this was most explicit in the establishment of Boas's four-field approach in the United States after the turn of the nineteenth century, whereas much older German influences had taken on quite different forms since the late eighteenth century in the formation of Russian physical anthropology and ethnography. Less well-known and more dispersed elements of German contributions to the formation of global anthropology before 1914 could be added. They would include the recognition of works by Georg and Johann Reinhold Forster, contributions by Gustav Klemm and by Theodor Waitz to the early formation of British anthropology, ${ }^{27}$ perhaps even the contested role of Carl Strehlow's and his son's work in the formation of anthropology in Australia, ${ }^{28}$ and several others. While most of these intellectual influences had been creative and productive, some others certainly had the opposite effect. Promitzer's study ${ }^{29}$ of the formative phase of a racist physical anthropology in Serbia, initiated by a Slovene disciple of Johannnes Ranke, is a telling example. Similar cases could also be made of some of the Herderian influences upon several among the more chauvinist versions of the new folklore studies in parts of northern, east Central, and southeastern Europe. After the establishment of the "second" German Empire in 1871, German and Austrian sociocultural and physical anthropologists certainly played their increasing part in aggressive colonial expeditions and in the construction of European colonial, missionary, and orientalist supremacy over the rest of the world. At the same time, the intellectual contributions and influences from the German-speaking countries to anthropological reasoning before 1914 continued to comprise a liberal element, an amount of respect for linguistic diversity, and a productive component of interdisciplinarity between the natural sciences and the humanities. ${ }^{30}$

27 Gingrich, "Ruptures, Schools and Nontraditions," 61-153.

28 Anna B. Kenny, "From Missionary to Frontier Scholar: An Introduction to Carl Strehlow's Masterpiece 'Die Aranda- und Loritja- Stämme in ZentralAustralien' (1901-1909)" (PhD thesis, University of Sydney, 2008).

29 See Christian Promitzer in this volume.

30 H. Glenn Penny and Matti Bunzl, eds., Worldly Provincialism: German Anthropology in the Age of Empire (Ann Arbor, MI: University of Michigan Press, 2003). 
In the last years before the war, liberalism in many parts of German-speaking academia came under increasing pressure. This was so not only because of the growing rivalries between the big powers, and of the minor armed conflicts in Europe that preceded the Great War, but also in view of armed persecution of indigenous revolts in the colonies. For example, the Herero revolt in today's Namibia, the ensuing massacres and detentions, and their media representation in Germany and Austria ${ }^{31}$ provoked some lukewarm regret, but did not elicit any serious protests from liberal German-speaking anthropologists that we know of today. In itself, this is another indicator for the erosion of liberalism in German-speaking anthropology. It suggests that the voices of those in German anthropology like Eugen Fischer-who had an explicit racist agenda and who supported brutal repression in what was called German Southwest Africa $^{32}$ - grew stronger.

The outbreak of World War I therefore not only accelerated the further erosion of the few remaining liberal elements of anthropology in the Germanspeaking countries, but also cut off these decaying liberal elements from their counterparts on what was now the enemies' side. The war also upgraded and promoted the militant and chauvinist voices in German-speaking academia in general as much as in anthropology in particular, and it made many among those who had formerly been more liberal change their minds. ${ }^{33}$ In addition, World War I also changed the contexts of what previously had been established as lively, liberal German intellectual influences in those non-German-speaking countries where they had been absorbed. There, the outbreak of the war, by necessity, had to accelerate the integration of those older German influences into the new national contexts of an ongoing war against German-speaking powers.

What had been a late colonial and imperial form of global anthropology thereby became more rapidly and more rigidly compartmentalized and cut up into national and quasi-national anthropologies through the outbreak

31 See Wolfgang Fuhrmann in this volume.

32 Bernhard Gessler, Eugen Fischer (1874-1927): Leben und Werk des Freiburger Anatomen, Anthropologen und Rassenhygienikers bis 1927 (Frankfurt a. M.: Lang, 2000); Niels C. Lösch, Rasse als Konstrukt: Leben und Werk Eugen Fischers (Frankfurt a. M.: Lang, 1997).

33 Anja Laukötter, Von der "Kultur" zur "Rasse"-Vom Objekt zum Körper? Völkerkundemuseen und ihre Wissenschaften zu Beginn des 20. Jahrhunderts (Bielefeld: Transcript Science Studies, 2007); Maria Six-Hohenbalken, "Felix von Luschans Beiträge zur Ethnologie-Zwischen imperialem Liberalismus und den Anfängen des Sozialdarwinismus," in Felix von Luschan-Arzt, Anthropologe, Forschungsreisender und Ausgräber: Akten des Symposions zu seinem Leben und Wirken, eds. Peter Ruggendorfer and Hubert Szemethy (Vienna: Böhlen, 2009), 165-193. 
of, and during, the war. Inside the German-speaking countries and their anthropology, this had the additional effect of strengthening international isolation and of accelerating the erosion of the liberal legacy.

\section{A Uniquely Intense InVolvement in World War I}

The chapters in this volume clarify the uniquely intense engagement of German-speaking anthropologists in World War I-related activities. This is not to say that there was no involvement at all by anthropologists elsewhere. But in those other cases, it was either a fairly routine continuation of preWorld War I activities, as in the Russian army's physical anthropology before 1917 , or a minor additional aspect as in the UK or in Bulgaria, or even an individual initiative as in the Serbian case. Some cases still require more research to determine the actual nature and possible extent of any involvement by anthropologists. The evidence and analyses that are available so far, however, very clearly suggest that anthropologists' involvement in World War Irelated activities was nowhere as intense as it was on all levels in Germany and in Austria. In addition to their contributions to propaganda and intelligence, folklore studies, physical, and sociocultural anthropology actively pursued large-scale programs of measurement among POWs as well as military research expeditions, and they carried out ethnographic, visual, and acoustic documentation in camps as well as during those expeditions. ${ }^{34}$

A fair percentage-perhaps almost a quarter-of professional anthropologists in Germany and Austria, in addition to other professionals and students, participated for varying periods in these activities. ${ }^{35}$ Some of the field's key officeholders were the driving force (Felix von Luschan, Rudolf Pöch, Arthur Haberlandt), for some it was a peak of their career (Alois Musil ${ }^{36}$ ), while quite a few others who would go on to become relatively prominent either based their subsequent careers on, or promoted them by means of, these war-related ac-

34 See contributions to this volume by Margit Berner, Andrew D. Evans, Britta Lange, Christian Marchetti, Ursula Reber, Margaret Olin, and Monique Scheer; see also Britta Lange, "Ein Archiv von Stimmen: Kriegsgefangene unter ethnografischer Beobachtung," in Original/Ton: Zur Mediengeschichte des O-Tons, vol. 34, Kommunikation audiovisuell, eds. Harun Maye, Cornelius Reiber, and Nikolaus Wegmann (Constance: Universitätsverlag Konstanz, 2007), 317-342.

35 This first and very rough quantitative estimate relates to the total of museum and university professionals who were primarily engaged in anthropological activities, that is, in the narrower sense of the three subfields discussed here. Theologian and ethnographer Alois Musil's Middle Eastern activities during World War I have been described best by Karl Johannes Bauer, Alois Musil: Wahrheitssucher in der Wüste (Vienna: Böhlau, 1989). 
tivities (Leo Frobenius, Michael Haberlandt, Erich M. von Hornbostel, Robert Lach, Viktor Lebzelter, Otto Reche, Egon von Eickstedt, and Josef Weninger). Indeed, nothing of a comparable scale and intensity went on in anthropology in any other of the main countries involved in the war.

A consideration of the main reasons and motives behind this unique engagement by German-speaking anthropologists has to start with their countries' position in the war. Germany was a very young and thus relatively aggressive newcomer in the late imperial and colonial global competition. As its main war ally, the old Austro-Hungarian Empire by contrast was increasingly lagging behind in this global rivalry in many key areas. For these different sets of reasons, a sense of the urgent need for extra effort was certainly widespread in leading academic circles in both countries.

In 1914, anthropologists in Germany and Austria could already look back at a fairly continuous record of cooperation between some of their own major projects and expeditions and their countries' armies and civil authorities. ${ }^{37}$ This record had ranged from Rudolf Virchow's first Schulstatistik project to the military's logistic support since 1900 for German and Austrian research expeditions in several parts of the world, including Oceania and South Arabia. After the outbreak of World War I, the thought of continuing and reinvigorating this earlier cooperation became an easy scenario to envision. International academic relations largely being cut off, any thought of increasing academic research almost unavoidably had to involve domestic state and army support and, at the very least, such extra activities had to be made to appear useful.

From the scholars' point of view, state loyalty and war enthusiasm played their part. In Germany and Austria, the war's outbreak was accompanied by a public enthusiasm for war that had few parallels in history. ${ }^{38}$ This mass enthusiasm, of course, was instigated and orchestrated by those in power, and it gradually became less joyful as the war dragged on. Still, it would be quite unrealistic to assume that a state-sponsored academic establishment in Germany and Austria was left untouched by such public enthusiasm. In view of the liberal paradigm's ongoing erosion before the war within anthropology, and in view of the fact that the large majority of political forces-including Liberals and Social Democrats-backed the declarations of war, it is far more realistic to work with the hypothesis that the large majority of German and Austrian anthropologists actively supported their countries' war from the outset. These are some of the main political, institutional, and ideological factors that I can

37 Andre Gingrich, "Liberalism in Imperial Anthropology: Notes on an Implicit Paradigm in Continental European Anthropology before World War I," Ab Imperio 8, no. 1 (2007): 224-239.

38 Manfried Rauchensteiner, Der Tod des Doppeladlers: Österreich-Ungarn und der Erste Weltkrieg, 2nd ed. (Graz: Steirische Verlagsgesellschaft, 1998). 
identify as key contexts for the fact that, during World War I, German and Austrian anthropologists launched war-related engagements which, by their scope as well as by their unique intensity, were definitely quite different from what went on in anthropology during World War I in most other countries.

These contexts also provide a better understanding of the main motives. Most of these major anthropological war-related projects were initiated by the scientists themselves. As far as we know, they did not originate as requests by the military or political authorities "from above," but as scholarly proposals and project applications "from below" to these authorities, whose representatives then took some time to consider them before they were convinced and agreed. The German and Austrian imperial authorities thus had to be persuaded that these anthropological projects were acceptable and potentially useful for them.

In their written proposals and reports, the scholars engaging with POWcamp studies and expeditions explicitly mentioned two main motives. These projects would be useful anthropological contributions to the Central Powers' war effort, and, simultaneously, the war would represent unprecedented opportunities for scholarly research. It may very well be that the anthropologists actually believed in the first of these two motives, that is, providing improved knowledge about enemies in order to further optimize the Central Powers' chances for victory. The results and research reports delivered during the war indicate, however, that any such claims, promises, and expectations were far too optimistic. If not as a realistic plan, then at least as a rhetorical pretext, the claims to be able to deliver serious academic contributions were nevertheless a diplomatic necessity in convincing the authorities. Sooner or later, this would combine with a minor and implicit reason that could never be openly talked about. Creating war-related research opportunities made applicants look good in the eyes of the military and political authorities. Thus, these projects might also provide enough reasons for the authorities not to draft the actors themselves into active military service. In specific cases, this implicit motive shines through between the lines, as shown for the examples of Wolfgang Schultz ${ }^{39}$ and Michael Haberlandt. ${ }^{40}$

In short, the first among the two explicit motives discussed here represented a diplomatic and rhetorical necessity and, perhaps, also a sign of loyalty and enthusiasm, but it hardly represented any realistic goal. In fact, if we assess Germany's and Austria's anthropological war projects according to their actual utility for their countries' war efforts, then the results were largely irrelevant in any substantial military sense. Monique Scheer ${ }^{41}$ makes this very clear. If anything, these projects sometimes served as the opposite of a contribution to the war, namely, as a good pretext for evading military service.

39 See Britta Lange in this volume.

40 See Christian Marchetti in this volume.

41 See Monique Scheeer in this volume. 
In practical terms, German and Austrian World War I anthropological projects therefore reinvented major areas of their own fields along more chauvinist and less liberal lines by benefiting from the war, while they largely failed as contributions to the war. The second explicit "research opportunity" motive thus turned out to be the most enduring. Academic expeditions in an army context promised new fieldwork and documentation activities in situ; POWcamp inquiries were seen as condensed fieldwork opportunities ex situ, which might work faster, cheaper, and on a larger scale.

It was pointed out in the first part of this chapter that before, during, and after the war, anthropologists in North America and most countries of Europe reinvented their field along very diverse national and quasi-national lines. The German and Austrian POW-camp and military expedition projects during World War I thus can now be identified as the crucial vehicles by which the new national traditions in Germany and Austria came into being. Among the POWs who were subjected to the camp projects, and among the colonial subjects in the Balkan peninsula, in Africa and western Asia where the expeditions were carried out ${ }^{42}$, these anthropological activities in times of war took a painful toll in terms of human dignity and also human lives. Among the German and Austrian anthropologists involved, these projects standardized and routinized the supremacist, orientalist, ${ }^{43}$ and chauvinist normality of their research procedures. The human individuals with and among whom this kind of research was carried out were construed as "colonial/oriental" inferior objects with little will of their own. Machines and tools of measurement and documentation shaped the reified relation between superior "white" researchers and their inferiorized and dehumanized alien objects of research. Physical anthropology now set the tone of the inquiry, while the humanities assisted them as mere auxiliary forces.

\section{A New Triangular Setting for Anthropology in Germany AFTER 1918}

For a sober assessment of anthropology's development in Germany and Austria after World War I, it does not suffice to merely examine what happened during the first few years after 1918. At first, the turmoil and revolutionary crises accompanying the collapse of both monarchies left little room for any

42 Good overviews on these specific topics are provided by Peter Jung, Der k.u.k. Wüstenkrieg: Österreich-Ungarn im Vorderen Orient, 1915-1918 (Graz: Styria-Militärhistorischen Dienst, 1992), 128; and by Thomas Zitelmann, “Des Teufels Lustgarten: Themen und Tabus der politischen Anthropologie Nordostafrikas" (habilitation thesis, Freie Universität Berlin, 1999).

See Diana Reynolds Cordileone in this volume. 
substantial academic developments. Germany had lost all its former colonies overseas, and the Austro-Hungarian Empire had literally been dismantled. Severe restrictions and several obligations were imposed upon the German and Austrian remainder states, among them the prohibition of any unity between both of them. In addition to the political crises, public budgets were so depleted that the mere maintenance of anthropological positions and institutions was a permanent problem. Assessing the emerging new institutional setting after World War I in anthropology in these two countries also requires the consideration of medium-term developments. It is therefore more useful to examine where that new setting was leading to and to take the late 1920s as a timeline for such an examination. In spite of the peace treaties' ban on any political Anschluss, many central institutional, academic, and civil society developments in Austria at first followed those in Germany to such an extent that my account of anthropology in those years will continue to treat this as a single process.

In the decade following 1918, the new institutional setting very gradually emerged in Germany and Austria. This new setting was the result of developments before and during the war; its emergence had definitely been promoted by anthropological engagements with war-related activities, and it became determined by the war's outcome: Colonies and empire were gone, and, instead, new and relatively weak nation-states were installed. It took a decade after the war for Germany's Weimar Republic and what would be called Austria's First Republic to become as stabilized as they would ever get-before being hit by the next world economic crisis and before the decisive rise to power of National Socialism and fascism. The year 1928, therefore, provides a fairly good timeline for assessing the kind of institutional setting which finally prevailed in anthropology's new postwar (and interwar) republican contexts in the German-speaking countries.

By the late 1920s, a new "triangular" setting for the anthropological disciplines had become the dominant pattern at universities and museums in the German-language zone. This triangular pattern comprised:

- A significant rise in the weight and importance of physical anthropology: This included the strengthening of existing, and the addition of some new, university chairs, the establishment in 1927 of a specialized section of the Kaiser-Wilhelm-Gesellschaft (today's Max Planck Society), and enlarged sections for physical anthropology either at the museums for Völkerkunde or at the natural history museums. ${ }^{44}$

- The early establishment of specialized folklore studies [Volkskunde] chairs and departments at the universities. As a plethora of specialized museums, journals, and academic associations, folklore studies had

44 Gessler, Eugen Fischer (1874-1927); Lösch, Rasse als Konstrukt. 
emerged in the nineteenth century. As a distinct field of university degrees, chairs, and departments, it was institutionalized after 1918 and remained loosely intertwined with physical anthropology: Research in German cultures often claimed a possible correspondence with notions of a German race. ${ }^{45}$

- The slower establishment of sociocultural anthropology [Völkerkunde] as a field with merely partial independence from physical anthropology, in so far as both fields continued to be jointly represented by some major museums (must notably in Berlin), in some anthropological societies (esp. those in Berlin and Vienna), and through some university chairs (e.g., Vienna until 1927 and Leipzig after 1927). By 1928, I count four university chairs or departments for sociocultural anthropology that had been established (in addition to the oldest, Leipzig, there were Hamburg, Frankfurt, and Vienna ${ }^{46}$ ).

Both the fields of folklore studies and sociocultural anthropology therefore succeeded during the postwar decade in gradually shifting some of their academic centers away from the museums that were their main prewar base and installing themselves with some weak independence from physical anthropology within the universities. Folklore studies succeeded in this regard more quickly and to a greater extent, while sociocultural anthropology took longer and had a lesser impact in this endeavor.

What was said in the first part of this chapter now demonstrates that this priority for folklore studies was clearly part of wider developments in parts of northern, Central, and southeastern Europe at the time, with some very weak parallels in the United States. ${ }^{47}$ By contrast, the belated and weaker installation of sociocultural anthropology was related to the loss of all colonial realms, on the one hand. On the other hand, the Western examples of the US, the UK, and France, as well as the domestic expertise and the collections, which

45 Wolfgang Jacobeit, Hannjost Lixfeld, and Olaf Bockhorn, eds., Völkische Wissenschaft: Gestalten und Tendenzen der deutschen und österreichischen Volkskunde in der 1. Hälfte des 20. Jahrhunderts (Vienna: Böhlau, 1994). In 1938, the official documents related to potential candidates for the vacancy in Vienna referred to five other chairs in the "Reich"—where the Völkerkunde chairs in Cologne and Göttingen had, however, been fully established after 1930 (Julia Gohm and Andre Gingrich, "Rochaden der Völkerkunde: Hauptakteure und Verlauf eines Berufungsverfahrens nach dem 'Anschluss,"' in Geisteswissenschaften im Nationalsozialismus: Die Universität Wien 1938-1945, eds. Mitchel G. Ash, Wolfram Nieß, and Ramon Pils (Göttingen:V \& R unipress, in press).

47 In Austria, the paradigmatic change from multicultural, imperial folklore studies before 1918 to a national and, at times, pan-German orientation after 1918 was even more drastic (see Christian Marchetti in this volume). 
both remained, nevertheless led to the installation of weaker, distinct forms of sociocultural anthropology at the university levels in Germany and Austria. The priority for folklore studies therefore reflected Germany's and Austria's enforced transformation into new nation-states and, in that sense, was part of a wider eastern and northern European development. The distinct establishment of Völkerkunde at the university level, by contrast, reflected developments in Britain and France and confirmed the continuity of colonial and imperial interests.

The physical anthropology that emerged in Germany and Austria after the war had only very little in common with its counterparts in the West. In the United States, Boasian physical anthropology was an independent and equal, nonracist partner subfield in the four-field approach. In the UK and France, physical anthropology was part of the natural sciences, with very little, if any, interaction with social anthropology as part of the social sciences. By contrast, in Germany and Austria, physical anthropology emerged after 1918 as an upgraded biological field that felt it had-and claimed to have-high relevance for a weakly institutionalized and largely historical sociocultural anthropology [Völkerkunde] and for the stronger, new academic discipline of folklore studies [Volkskunde].

The triangular pattern, which we have identified here as the main institutional outcome of the decade following World War I, therefore provided a relatively unusual new quasi-national context for the anthropological fields in Germany and Austria. Few other major national or quasi-national fragments of the global, late imperial academic landscape that had collapsed in 1914 developed similar institutional articulations for the fields of anthropology after the war. ${ }^{48}$

The German-Austrian triangle of a dominant physical anthropology, a not fully independent sociocultural anthropology, and a separate field of folklore studies had drifted far away from the US trajectory with which it previously had shared some common origins; and, by comparison, it differed from the French

48 If the German-Austrian triangular setting in the anthropology of the postWorld War I era had any close parallels elsewhere, then they cropped up during the same years in parts of Scandinavia and southern Europe (Italy, Spain, and Portugal) - in short, among some minor colonial powers. In these cases, however, folklore studies usually took the exclusive lead at the university level, whereas variants of ethnology or sociocultural anthropology had their main place in the museums. The possible correlation between variants of a triangular institutional pattern in anthropology and fascist political developments in several of these countries during the 1920s and 1930s is interesting and deserves further exploration. See Christian Lindberg, "Anthropology on the Periphery: The Early Schools of Nordic Anthropology," in Kuklick, A New History of Anthropology, 161-172. 
and British settings even more strongly than from its Soviet counterparts. The triangular institutional constellation for post-World War I anthropology in Germany and Austria thus was a relatively specific, postimperial setting for the main losers in the Great War. By its inherent priorities, it signaled claims toward nationalist reinvigoration and the desire to win back lost colonies.

\section{Epilogue}

The triangular institutional pattern that dominated in the German-speaking anthropological fields by the late 1920s must not be confused with the changing networks of academic actors contesting for, and competing within, these institutions. The triangular pattern from the late 1920s does indicate which forces won the upper hand in these internal academic contests, and it also demonstrates that this was supported or accepted by the deciding forces in academic and political hierarchies. Yet, the pattern itself certainly does not tell us about the diversity of interests, alliances, and actors that were involved in German and Austrian physical anthropology, Völkerkunde, and Volkskunde during those years.

For German physical anthropology's theories and methods, Andrew Evans ${ }^{49}$ argues that these followed more nationalist and racist orientations after the war than before, when a liberal paradigm was still relatively influential. During the Weimar Republic, the field increasingly became dominated by figures like Eugen Fischer, Hans Günther, and Egon von Eickstedt. In addition, Margit Berner ${ }^{50}$ has demonstrated that, in the Vienna university version of this field, much less liberal orientations had prevailed from the outset, which was continued by Pöch's disciple Weninger even more rigidly.

For Volkskunde in Germany and Austria, Reinhard Johler's analysis ${ }^{51}$ indicates a somewhat stronger element of liberal continuity after 1918, in spite of the now explicitly national agenda for this field in its postimperial contexts. German-speaking academia in the 1920 s tended to be more conservative than the societies at large at the time, and several main actors in German-speaking anthropology belonged politically to the far right within this largely conservative spectrum. Still, some segments of the rank and file of Volkskunde continued to deliver useful and interesting results during the 1920 s.

49 See this volume; Andrew D. Evans, "A Liberal Paradigm? Race and Ideology in Late Nineteenth Century German Physical Anthropology," Ab Imperio 8, no. 1 (2007): 113-138.

50 See this volume.

51 See Reinhard Johler in this volume. 
In fact, it is worth noting that, for historical ethnographies of Central Europe, or of southeastern Europe for that matter, a critical reading and careful interpretative usage of many research results by German and Austrian Volkskunde from before 1933/34 remains indispensable to this day. The same can hardly be claimed for physical anthropology from these years, for example, of Weninger's volume about West Africa, ${ }^{52}$ which had resulted from his own and Pöch's POW-camp investigations. Apart from studies in the history of science, I know of no current physical anthropologists who would use these data for any reasonable present-day or historical research purpose. ${ }^{53}$

In retrospect, it has thus become much clearer than it already was that German-speaking physical anthropology was increasingly developing into a highly speculative, noncumulative dead end, with little potential other than serving as a legitimizing tool for reactionary and racist political goals. Folklore studies, by contrast, did continue to document ethnographic evidence. Some of it was highly biased by national and historical-diffusionist priorities, and much of what would have been important was not even considered for research. Still, this biased and partial ethnographic evidence from the past cannot be totally discarded today.

Although Völkerkunde was the weakest among the three disciplines in the triangle, the record looks even more diverse and potentially interesting for sociocultural anthropology in its German interwar dimensions before 1933. Elsewhere, I have outlined the rich theoretical and methodological plurality of those years, which included incipient German-speaking versions of most major international research orientations, in addition to a few specifically German-speaking approaches. ${ }^{54}$ To an extent, the loss of the colonies in fact reinvigorated an older German and Austrian anthropological tradition in which some of the best ethnographic research had been carried out outside any colo-

52 Britta Lange and Andre Gingrich, "Gefangene Stimmen, Internierte Körper: Rudolf Pöch, die Wünsdorf-Reise 1917 und die Frage der Geschichte der Völkerkunde," in Archivhorizonte: Wissenslandschaften und Perspektivgrenzen im multimedialen Nachlass des Anthropologen und Forschungsreisenden Rudolf Pöch, eds. Thomas Ballhausen, Katarina Matiasek, and Maria Teschler-Nicola (Vienna: Löcker, in press).

53 This retrospective contrast between the proud claims for research budgets by some fields of the natural sciences, and their results, which produced no useful cumulative effect in any sense whatsoever, is not only interesting in itself, but also if compared against the much more enduring cumulative quality of some of the ethnographic research referred to here. Both would also provide interesting material for present-day debates about the unequal distribution of research funding in Europe.

54 Gingrich, "Ruptures, Schools and Nontraditions." 
nial or missionary realm of those countries. ${ }^{55}$ Still, within Völkerkunde the triangular institutional pattern also favored the more conservative, missionary, and procolonial forces, who could claim to represent truly national interests. They were explicitly compatible with parallel orientations in physical anthropology and folklore studies and often reinforced each other. By 1928, the four university chairs or departments were all held by representatives of one or the other school of historical diffusionism. They were thus inspired by theories that were highly speculative and, with few exceptions, far removed from any liberal orientations. Most of the more productive and innovative research was carried out by researchers other than the holders of those positions.

To sum up, the German-speaking anthropological institutional triangle of the post-1918 decade favored the further rise of a dominating physical anthropology and kept Volkskunde and Völkerkunde closely within the former's range. Within these two latter subfields, the triangle did allow for some remarkable pluralism of research — but for the key academic positions, this institutional development favored the installation of historical diffusionism mostly in its nonliberal and speculative versions.

In contrast with Boas's four-field approach in the USA, not to mention social anthropology's sociological orientation in the UK and France, anthropology's institutional triangle in the German-language zone therefore turned out to be more of an obstacle than a useful vehicle for pluralistic and fruitful academic research.

This was decisively aggravated by the biographical background of some of the key actors in the triangle's central positions. They had been missionaries since the pre-World War I era (Diedrich Westermann and Pater Wilhelm Schmidt); they had gained some of their empirical academic experience before and during World War I in the colonies (Eugen Fischer, Leo Frobenius, Arthur and Michael Haberlandt, and Richard Thurnwald); and, in addition, some of them had established the empirical basis of their careers in the POW-camp projects (Otto Reche, Egon von Eickstedt, and Josef Weninger).

The decade after 1918, therefore, was a contested period in German-speaking anthropology, in which not everything was yet decided. But as a result, the triangular institutional setting emerged as a dominant pattern and favored illiberal, racist, orientalist, and nationalist orientations more than others. In this triangular pattern, key players rose to dominant influence whose professional biographies had been shaped by ideologies and experiences of religious, colonial, or national supremacy.

Inside the German Weimar Republic and the Austrian First Republic, this introduced deep hierarchies into these particular segments of academic life. At the same time, these internal constellations gave German-speaking anthropol-

55 Penny and Bunzl, Worldly Provincialism. 
ogy a new and distinct quasi-national profile set apart from others. Sometimes, this profile included interesting potential for international exchange and communication. More frequently, however, some of its leading representatives and their works were understood internationally as representing a new nationalist orientation that was heading toward confrontation, again. 
